\title{
Kajian Feminisme dan Nilai Pendidikan dalam Novel Habibie \& Ainun Karya Bacharuddin Jusuf Habibie
}

\author{
Wahyu Puji Lestari ${ }^{1)}$ \\ Universitas Indraprasta PGRI \\ Jalan Nangka No. 58 C/TB. Simatupang, Tanjung Barat, Jakarta Selatan 12530 \\ Sumaryoto ${ }^{2)}$ \\ Universitas Indraprasta PGRI \\ Jalan Nangka No. 58 C/TB. Simatupang, Tanjung Barat, Jakarta Selatan 12530 \\ Mamik Suendarti ${ }^{3)}$ \\ Universitas Indraprasta PGRI \\ Jalan Nangka No. 58 C/TB. Simatupang, Tanjung Barat, Jakarta Selatan 12530 \\ azrinashazfa222@gmail.com ${ }^{1)}$
}

\begin{abstract}
The purpose of this study is to describe and explain: 1) Feminism aspects in the novel Habibie \& Ainun by Bacharuddin Jusuf Habibie. 2) The existence of women in the novel Habibie \& Ainun by Bacharuddin Jusuf Habibie. 3) Main points of feminism in the novel Habibie \& Ainun by Bacharuddin Jusuf Habibie. 4) Educational values in the novel Habibie \& Ainun by Bacharuddin Jusuf Habibie. The method used in this research is descriptive qualitative method with a structural approach. Data collection techniques used are noninteractive techniques which include recording documents or archives (content analysis), non-role observation, observation and note-taking techniques, and library research techniques. Data validation using triangulation. The results of this study are as follows: 1) Feminism aspects in the novel which include women and education, women and the world of work / career, women and households; 2) The existence of women in the novel Habibie \& Ainun by Bacharuddin Jusuf Habibie includes: equal position in the fields of education and work, freedom of choice, and plays an important role as wives and mothers in the household; 3) The main ideas of feminism in the novel Habibie \& Ainun by Bacharuddin Jusuf Habibie include: intelligent female figures, independent female characters and willing to sacrifice \& tough and; 4) Educational values in the novel Habibie \& Ainun by Bacharuddin Jusuf Habibie include: religious values, moral values, social values and cultural values.
\end{abstract}

Keywords: Novel Habibie \& Ainun, Feminism Studies, Educational Value

\begin{abstract}
Abstrak
Tujuan penelitian ini adalah untuk mendeskripsikan dan menjelaskan: 1) Aspek Feminisme dalam novel Habibie \& Ainun karya Bacharuddin Jusuf Habibie. 2) Eksistensi perempuan yang terdapat dalam Novel Habibie \& Ainun karya Bacharuddin Jusuf Habibie. 3) Pokok-pokok pikiran feminisme dalam novel Habibie \& Ainun karya Bacharuddin Jusuf Habibie. 4) Nilai-nilai pendidikan dalam novel Habibie \& Ainun karya Bacharuddin Jusuf Habibie. Metode yang digunakan dalam penelitian ini adalah metode deskriptif kualitatif dengan pendekatan struktural. Teknik pengumpulan data yang digunakan teknik noninteraktif yang meliputi mencatat dokumen atau arsip (content analysis), observasi tak berperan, teknik simak dan catat, dan teknik riset pustaka. Validasi data menggunakan triangulasi. Hasil penelitian ini adalah sebagai berikut : 1) Aspek Feminisme dalam novel yang meliputi perempuan dan pendidikan, perempuan dan dunia kerja/karir, perempuan dan rumah tangga; 2) Eksistensi perempuan yang terdapat dalam novel Habibie \& Ainun
\end{abstract}

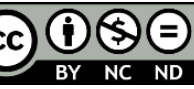

Creative Commons Attribution-NonCommercial-NoDerivatives 4.0 International License 
karya Bacharuddin Jusuf Habibie meliputi : kedudukan sama dalam bidang pendidikan dan pekerjaan, kebebasan menentukan pilihan, dan berperan penting sebagai istri dan ibu dalam rumah tangga; 3) Pokok pikiran feminisme dalam novel Habibie \& Ainun karya Bacharuddin Jusuf Habibie meliputi : sosok perempuan cerdas, kemandirian tokoh perempuan serta rela berkorban \& tangguh dan; 4) Nilai-nilai pendidikan dalam novel Habibie \& Ainun karya Bacharuddin Jusuf Habibie antara lain : Nilai Agama, Nilai moral, nilai sosial dan nilai budaya.

Kata kunci : Novel Habibie \& Ainun, Kajian Feminisme, Nilai Pendidikan

\section{PENDAHULUAN}

Salah satu wujud kebudayaan yang mengandung kajian atau refleksi atas aktivitas kesehariannya adalah sastra. Sastra merupakan hasil seni kreatif yang objeknya adalah manusia beserta kehidupannya dengan menggunakan bahasa sebagai mediumnya (Semi, 1988 : 8). Sebuah karya sastra merupakan kisahan yang senantiasa bergumul dengan para tokoh fiksional yang diciptakan oleh si pengarang (Minderop, 2010).

Penulis tertarik untuk mengkaji sebuah karya sastra berupa novel. Penelitian novel yang dimaksud ini adalah novel nonfiksi karya Bacharuddin Jusuf Habibie yang berjudul Habibie dan Ainun. Pilihan untuk mengangkat dan membahas novel Habibie dan Ainun ini adalah dengan pertimbangan : Pertama, melihat sisi dari novel tersebut yang mengandung kajian yang mendasar dalam kehidupan perempuan. Aspek-aspek feminisme yang menunjukkan peranan-peranan perempuan dalam dunia pendidikan, bagaimana seorang perempuan bisa berprestasi dalam dunia pendidikan dan disegani karena mampu sejajar dengan kaum laki-laki didalam dunia pendidikan. Seorang perempuan harus cerdas karna ia akan menjadi pendidik bagi generasinya. Dan caraya adalah dengan diperbolehkannya seorang perempuan mengenyam pendidikan hingga tingkat yang paling tinggi yang juga dilakukan oleh laki-laki. Tidak ada deskriminasi tentang pendidikan, karena ditangan perempuan, akan lahir generasi penerus bangsa yang cerdas yaitu seorang anak. Ditangan perempuan, akan lahir laki-laki hebat dan sukses yaitu suami dan ditangan perempuan pula maka akan tercipta keharmonisan keluarga karena kemampuannya dalam mengatur segala kebutuhan dan mengelola keuangan dengan baik.

Kedua, novel Habibie dan Ainun merupakan kisah cerita nyata dari kehidupan yang harmonis. Sehingga Habibie sebagai penulis menceritakan faktafakta yang tercemin dari sifat-sifat ainun yang mempunyai posisi dan peranan yang yang sangat penting dalam kehidupan Habibie. Selain sosoknya yang begitu anggun dan lembut, beliau adalah wanita cerdas yang selalu mendampingi Habibie dalam suka maupun duka. Ketiga, isi novel ini sangat menginspirasi kaum perempuan yang menginginkan dan mendambakan sebuah rumah tangga yang bahagia. Mengapa? Karena banyak pelajaran yang dapat dipetik dan diterapkan dalam kehidupan berumah tangga dari novel yang berjudul Habibie dan Ainun ini. Seperti perumpamaan yang diungkapkan oleh Buya Hamka "diibaratkan dalam sebuah rumah ada yang namanya tiang, jika tiang itu kokoh, maka kokohlah rumah itu dan jika ia rapuh maka condonglah rumah itu. Tiang tersebut adalah perempuan, jika perempuannya baik maka akan baik pula kehidupan rumah tangganya, dan jika 
perempuannya rusak maka goyahlah rumah tangganya. Begitupun dalam suatu bangsa, baik buruknya dapat dilihat dari kaum perempuannya”. Dari ketiga dasar inilah yang menjadi alasan di buatnya penelitian ini.

Kajian feminisme perempuan terdapat pada eksistensinya yaitu dalam dunia patriarki yang selalu dinomor duakan, mendapat tindakan kekerasan dan tidak adil, selalu diremehkan, subordinasi perempuan, dan kebebasan dalam menentukan pilihan. Karena pada kenyataannya perempuan yang sudah menikah hanya menjalankan kewajibannya sebagai Ibu Rumah Tangga dan kodratnya perempuan menikah adalah mengurus rumah, mengurus anak dan mengurus suami. Setelah tugas itu selesai, maka selesai sudah kewajibannya. Padahal, jika di kaji kembali maka peranan perempuan lebih dari sekedar itu. Banyak nilai-nilai yang terkandung dalam peranannya sebagai Ibu rumah tangga. Seorang perempuan dituntut harus mandiri dan bisa mencari solusi atas permasalahan kecil yang terjadi di dalam rumah tangga karena peranannya adalah sebagai Ibu Rumah tangga. Seorang perempuan juga dituntut untuk bisa berinteraksi secara sosial di dalam lingkungan dimana ia tinggal.

Dengan dasar novel sebagai alat untuk menyatukan pemikiran dan pengetahuan tentang pentingnya keberadaan perempuan di dalam keluarga maka dalam penelitian ini penulis memberi judul "Kajian Feminisme dan Pendidikan dalam Novel Habibie \& Ainun karya Bacharuddin Jusuf Habibie”. Kajian Feminisme dan nilai pendidikan disini merpakan hal yang sangat penting bagi penulis. Pentingnya disini dengan alasan : Pertama, Feminisme disini bukan untuk membahas mengenai pemberontakan perempuan teradap ketidak adilan namun kajian feminisme disini adalah peranan yang dijalankan sebagai seorang perempuan dalam dunia pendidikan, dunia kerja dan dunia rumah tangga. Kedua, telah terbukti bahwa dibalik laki-laki yang sukses ada perempuan hebat di belakangnya yang selalu mengiringi, menemani dan memotivasi setiap langkah pasangannya. Ketiga, masih banyak perempuan-perempuan khususnya di indnesia yang tidak tau bagaimana tugas dan peranannya sebagai perempuan dalam dunia pendidikan, dunia kerja dan dunia rumah tangga dalam kehidupannya.

Feminisme (tokohnya disebut feminis) adalah sebuah gerakan perempuan yang menuntut emansipasi atau kesamaan dan keadilan hak dengan pria. Feminisme juga terdiri dari beberapa bagian sosial, budaya, pergerakan politik, ekonomi dan teori-teori dan filosofi moral (Rokhmansyah, 2016:37). Kata feminisme dicetuskan pertama kali oleh aktivis soaial perancis Charles Fourier pada tahun 1837. Ide yang diusungnya adalah transformasi perempuan oleh masyarakat berdasarkan saling ketergantungan dan kerjasama, bukan pada kompetisi dan mencari keuntungan (Rokhmansyah, 2016:38).

Pada tahun 1963, Betty Frieden menerbitkan buku berjudul Feminine Mystique, dalam bukunya itu Frieden menyatakan bahwa peran tradisional wanita sebagai Ibu dan subjek yang mengerjakan pekerjaan rumah tangga adalah faktor utama wanita tidak dapat mengembangkan kepribadiannya. Selanjutnya dikatakan wanita tidak harus kawin dan mempunyai anak. Wanita dapat mengembangkan dirinya menjadi apa saja seperti yang dilakukan kaum pria.

Dengan tulisan Frieden ini feminisme menjadi gerakan yang mengejutkan masyarakat Amerika Serikat. Muncul kesadaran baru kaum perempuan Amerika 
bahwa peran tradisional perempuan ternyata telah menempatkan kaum perempuan dalam posisi yang tidak menguntungkan yaitu sebagai sub-ordinasi terhadap kaum laki-laki.

Sebagai gerakan sosial, feminisme ini mrupakan fakta historis yang perkembangannya melalui tiga tahap yaitu tahap domestik, tahap sosial budaya, dan tahap politis-ideologis. Pada tahap domestik gerakan feminisme menekankan perjuangannya pada upaya perlawanan terhadap peran dan posisi perempuan yang merupakan pusat urusan rumah tangga sebagai peran yang menindas dan mengkedilkan peran sesungguhnya kaum perempuan. Institusi keluarga menjadi penjara bagikaum perempuan. Pada tahap ini gerakan feminis melakukan upayaupaya dekonstruksi perempuan sebagai ibu rumah tangga. Pada tahap ini gerakan feminisme masih menjadi gerakan yang terbatas dan bersifat elitis.

Senada dengan pendapat di atas, Djajanegara (2000:3) mengatakan ada beberapa aspek yang turut mempengaruhi terjadinya gerakan feminisme, yaitu aspek politis, aspek evangelis dan aspek sosialime. Aspek politik, yakni ketika perempuan merasa tidak dianggap oleh pemerintah. Begitu pula tatkala kepentingan-kepentingan kaum perempuan berkaitan dengan politik diabaikan. Dari aspek agama disebutkan bahwa kaum feminis menuding pihak gereja bertanggung jawab atas doktrin-doktrin yang menyebabkan posisi perempuan dibawah kaum laki-laki. Aspek ketiga yaitu konsep sosialisme yang menganggap kaum perempuan merupakan suatu kelas dalam masyarakat yang ditindas oleh kelas lain, yaitu laki-laki.

Lebih lanjut, Djajanegara (2000:4) mengungkapkan bahwa feminisme adalah suatu gerakan yang memusatkan perhatian pada perjuangan perempuan dalam menempatkan eksistensinya. Dengan demikian, dapat disimpulkan bahwa tujuan feminisme adalah meningkatkan kedudukan dan derajat perempuan agar sama dan sejajar dengan kedudukan dan derajat laki-laki.

Dari paparan di atas, feminisme dapat diidentikan dengan upaya atau gerakan perempuan yang bertujuan meningkatkan kedudukan dan derajat perempuan agar sama atau sejajar dengan kedudukan serta derajat laki-laki di bidang apapun tanpa bertujuan menindas kaum laki-laki. Dengan begitu, kita dapat mengetahui adanya budaya patriarki yang masih membelenggu kaum perempuan. Namun seiring dengan perkembangan jaman kaum perempuan mampu beremansipasi sehingga membuat kedudukannya seimbang dengan laki-laki dalam bidang pendidikan, pekerjaan / karir dan dalam rumah tangga kaum perempuan dihargai dan dihormati.

\section{METODE}

Metode yang digunakan dalam penelitian ini adalah metode kualitatif yaitu mengumpulkan berbagai informasi berupa data-data yang diperoleh dari buku-buku (Arikunto, 2010) yang berhubungan dengan penelitian ini baik secara teoritis, maupun data faktual dari novel yang dikombinasi dengan pendekatan Struktural atau sering disebut pendekatan objektif, pendekatan formal atau pedekatan analitik untuk menganalisis dinamika cerita dalam novel sehingga diperoleh aspek 
feminisme, eksistensi perempuan dan pokok pikiran feminisme serta nilai pendidikan yang terkandung di dalamnya.

Dalam menjelaskan aspek feminisme dan nilai pendidikan dalam novel Habibie dan Ainun, penulis menjabarkannya secara deskriptif - analitis untuk menggambarkan kenyataan tentang peristiwa-peristiwa atau kejadian-kejadian yang ada sebagai ragkaian cerita dari novel tersebut. Teknik pengumpulan data yang digunakan teknik noninteraktif. Teknik noninteraktif meliputi mencatat dokumen atau arsip (content analysis), observasi tak berperan, teknik simak dan catat, dan teknik riset pustaka. Validasi data menggunakan triangulasi dan teknik analisis data menggunakan model noninteraktif. Data yang sudah terkumpul dianalisis dengan teknik analisis model analisis interaktif dengan tiga alur kegiatan 1) reduksi data, 2) penyajian data dan, 3) penarikan simpulan atau verifikasi.

\section{HASIL DAN PEMBAHASAN}

\section{Hasil}

Berdasarkan analisis data, diperoleh hasil sebagai berikut: 1) Aspek feminisme dalam novel Habibie \& Ainun karya Bacharuddin Jusuf Habibie. 2) Eksistensi perempuan yang terdapat dalam novel Habibie \& Ainun karya Bacharuddin Jusuf Habibie. 3) Pokok-pokok pikiran nilai feminisme dalam novel Habibie \& Ainun karya Bacharuddin Jusuf Habibie. 4) Nilai-nilai pendidikan yang terdapat dalam novel Habibie \& Ainun karya Bacharuddin Jusuf Habibie.

\section{Pembahasan}

\section{Aspek-aspek Feminisme dalam Novel Haibie\&Ainun karya Bacharuddin Jusuf Habibie}

Pengkajian aspek feminisme pada novel Habibie\&Ainun menekankan pada aspek feminisme dalam pendidikan, aspek feminisme dalam dunia kerja (karier) dan aspek feminsme dalam Rumah tangga.

1. Aspek Feminisme dalam Pendidikan

Pendidikan merupakan hal yang sangat penting dalam kehidupan moderen seperti sekarang ini. Tanpa pendidikan kita akan jauh dari pengetahuan. Sehingga sudah selayaknya jika pendidikan adalah jendela dunia.

Pendidikan adalah proses dimana seseorang mengembangkan sikap dan bentuk-bentuk tingkah laku lainnya di dalam masyarakat dimana dia hidup, proses sosial dimana orang dihadapkan pada pengaruh lingkungan yang terpilih dan terkontrol (khususnya yang datang dari sekolah), sehingga dia dapat memperoleh atau mengalami perkembangan kemampuan sosial dan kemampuan individu yang optimum.

Aspek feminisme dalam bidang pendidikan yang terdapat dalam novel Habibe\&Ainun adalah setelah pembaca memahami isi novel. Yaitu ketika seorang perempuan mendapatkan posisi yang sama dengan laki-laki dalam bidang pendidikan dan dengan prestasi yang lebih baik dari laki-laki. Karena 
perempuan memegang peranan penting dalam keluarga maka Ia harus mempunyai penetahuan yang luas untuk dapat melaksanakan tugasnya sebagai istri, ibu ataupun sebagai wanita karir.

Pendidikan juga dapat memengaruhi karier seseorang. Semakin inggi pendidikan maka semakin tinggi pula kesempatan menduduki posisi penting dalam sebuah pekerjaan. Pendidikan juga berpengaruh terhadap status sosial seseorang.

2. Aspek Feminisme dalam Dunia Kerja (Karir)

Bukan menjadi rahasia lagi jika saat ini banyak perempuan berperan penting dalam dunia kerja. Bahkan dalam pemerintahanpun sudah banyak diisi oeh kaum perempuan. Seperti halnya dalam novel Habibie\&Ainun menggambarkan posisi Ainun dalam dunia kerja yaitu keahlian sebagai dokter.

Seperti yang di ungkapkan oleh Soenarjati Djajanegara (2000:11) "Dewasa ini, ibu-ibu rumah tangga yang bekerja atau mencari nafkah diluar rumah sudah dianggap lazim. Kira-kira 50\% dari mereka membanjiri berbagai lapangan kerja. Bahkan menurut John Naisbitt, penulis buku Megatrends, setiap tahun kaum wanita menciptakan 200.000 lapangan kerja baru. Profesi-profesi dibidang perawatan orang lanjut usia, butik, komputer, pariwisata dan jasa boga, misalnya, banyak diminati mereka.

Selama ini kaum perempuan disubordinasikan dalam bidang pekerjaan karena dianggap lemah dan tidak mumpuni. Anggapan bahwa wanita sebaiknya dirumah saja mengerjakan pekerjaan domestik rumah tangga tidak berarti apaapa. Tidak ada penghargaan karena dianggap pekerjaan domestik itu tidak menghasilkan uang.

Namun, hebatnya seorang perempuan, Ia dapat mengerjakan pekerjaan diluar rumah dan di dalam rumah sekaligus, semuanya ia cakup. Ini merupakan aspek feminisme dalam bidang pekerjaan.

3. Aspek Feminisme dalam Rumah Tangga

Kamla dalam Sukron (2009) mengatakan bahwa menjadi seorang feminis tidak berarti bekerja di luar rumah tangga. Arti sesungguhnya adalah menjalani pilihan yang sebenarya yang didasarkan pada kesempatan yang sama. Unsur pemilihan, yakni pilihan yang sesungguhnya berdasarkan kemauan perempuan itu sendiri, adalah yang terpenting. Kamla juga berpendapat bahwa kaum feminis tidak mengecilkan atau merendahkan ibu rumah tangga atau pekerjaan rumah tangga. sebenarnya perjuangan pokoknya adalah agar pekerjaan rumah tangga diakui dan dihargai, sehingga perempuan yang melakukannya akan diakui, dihargai dan dihormati. Jika pekerjaan rumah tangga dihormati, dihargai serta dinilai memadai, kaum laki-laki tidak hanya mulai mengakuinya, tetapi mungkin juga mulai melakukannya (1995:30). Seorang feminisme dapat memilih menjadi ibu rumah tangga sepenuhnya bila hal itu memuaskan dirinya, dengan syarat bahwa dia dapat mempertahankan kamandirian dan kepribadiannya, serta bahwa pasangannya tidak menguasainya atas alasan bahwa perempuan tidak mencari nafkah (1995:32)

Aspek feminisme dalam rumah tangga pada novel Habiie\&Ainun karya Bacharuddin Jusuf Habibie sesuai dengan pendapat diatas. Keputusan yang dimbil oeh Ainun dalam mengabdikan diri untuk keluarga tanpa adanya 
paksaan, dan Habibie tidak merendahkan, meremehkan atau bahkan menguasai Ainun yang tidak bekerja. Semua dijalani Ainun dari keikhlasan hati, tanpa menggerutu, tanpa mempersoalkan hak untuk tetap bekerja diluar. Baginya keluargalah tempat Ia bekerja sekarang. Menjadi istri dari seorang laki-laki hebat dan menjadi ibu dari anak-anak yang cerdas, yang Ia bentuk dengan tangannya sendiri, bukan diserahkan kepada pembantu mengenai pendidikan anak.

\section{Eksistensi Perempuan dalam Novel Habibie\&Anun karya Bacharuddin Jusuf Habibie}

Eksistensi adalah kondisi dimana seseorang ingin diakui keberadaannya. Eksistensi baru dapat terlihat jika manusia itu berbuat sesuatu, dan dilihat oleh manusia lain agar diakui perannya. Dalam novel Habibie\&Ainun menunjukkan bahwa terdapat tiga poin utama eksistensi perempuan yaitu kedudukan sama dalam bidang pendidikan dan pekerjaan, kebebasan menentukan pilihan dan berperan penting sebagai istri dan ibu dalam rumah tangga.

1. Kedudukan Sama dalam Bidang Pendidikan dan Pekerjaan

Dalam sistem patriarki, perempuan di bedakan kedudukannya, baik itu dalam bidang pendidikan ataupun dalam bidang pekerjaan. Perempuan di nomor duakan, karena perempuan dipandang sebagai makhluk yang lemah. Bahkan perempuan sering diremehkan karena status dan kedudukannya. Tanpa mempertimbangka bahwa perempuan sebagai makhluk Tuhan juga dibekali dengan otak untuk berfikir sehingga perempuanpun juga bisa menjadi cerdas asalkan diasah kemampuan berfikirnya dengan diberikannya pendidikan yang baik, dan kesempatan untuk mengembangkan potensinya sesuai engan bakat yag dimilikinya.

Dalam novel Habibie\&Ainun karya Bacharuddin Jususf Habibie dapat dilihat bagaimana Ainun mampu menyamai kecerdasan laki-laki disekolahnya, sehingga mendapat sanjungan dari gurunya. Di duniakerjapun Ainun mendapatkan kesempatan yang sama sebagai dokter anak di RSCM. Karena kecerdasannya itu sehingga mengantarkannya pada posisi karir yang baik.

2. Kebebasan Menentukan Pilihan Bagi Perempuan dalam Novel Habibie \&

Ainun karya Bacharuddin Jusuf Habibie

Setiap manusia pasti pernah dihadapkan pada seuah pilihan. Namun terkadang tidak diperkenankan untuk menentukan pilihan tersebut. Dalam budaya patriarki perempuan tidak bebas menentukan pilihan karena laki-laki yang berkuasa atas istri ataupun anak perempuannya. Perempuan diminta menurut dan menjalankan apapun yang diputuskan oleh laki-laki. Sehingga hal inilah yang menimbulkan adanya gerakan feminisme sosialis.

Novel Habibie\&Ainun karya Bacharuddin Jusuf Habibie memberikan gambaran bahwa perempuan bebas menentukan pilihan hidupnya sendiri tanpa adanya tekanan dari laki-laki. Gambaran kebebasan menentukan pilihan terlihat dari: Pertama, keputusan Ainun untuk menempuh pendidikan, Ia bebas menentukan dimana Ia akan menuntut ilmu. Kedua, Ia bebas menentukan pilihan pekerjaan yang pas untuknya dan dimana Ia akan mengabdikan ilmunya. Ketiga, Ia bebas memilih pasangan hidupnya sendiri, artinya pernikahannya 
bukanlah hasil dari perjodohan dari kedua orang tua atau saudara laki-laki. Dan yang keempat, ia bebas menentukan pilihan untuk tetap berkarir atau menjadi ibu rumah tangga. Dengan demikian gerakan feminisme telah berhasil membebaskan perempuan dari kekangan dan tekanan kaum laki-laki.

3. Berperan Penting Sebagai Istri dan Ibu dalam Rumah Tangga

Seperti perumpamaan yang diungkapkan oleh Buya Hamka "diibaratkan dalam sebuah rumah ada yang namanya tiang, jika tiang itu kokoh, maka kokohlah rumah itu dan jika ia rapuh maka condonglah rumah itu. Tiang tersebut adalah perempuan, jika perempuan nya baik maka akan baik pula kehidupan rumah tangganya, dan jika perempuannya rusak maka goyahlah rumah tangganya.

Perempuan yang baik akan senantiasa menjadikan dirinya sebagai pelindung bagi keluarganya. Sifatnya yang penuh kasih sayang dan perhatianna terhadap suami dan anaknya adalah perihal yang wajib dimiliki oleh seorang perempuan. Pada dasarnya perempuan adalah sosok pemberi tanpa pamrih, sehingga pada hakikatnya laki-laki tak akan bisa hidup tanpa ada perempuan yang mendampinginya. Dengan perhatiannya, Ia mampu menciptakan rasa percaya diri suaminya. Dengan cintanya Ia bisa membuat laki-laki merasa dihargai. Sebagai istri, Ia mampu mendorong semangat laki-laki hingga menjadi sukses, dan sebagai Ibu Ia telah melahirkan generasi yang berkualitas dan membanggakan.

Dalam novel Habbie\&Ainun karya Baharuddin Jusuf Habibie telah digambarkan bahwa betapa pentingnya peran Ainun dalam keluarga yaitu sebagai istri dan ibu. Keberadaannya dalam keluarga menunjukkan sosok dibelakang Habibi yang senantiasa menjadi perempuan penginspirasi dalam kesusksesan Habibie. Beliau juga telah menjadikan dirinya sebagai pengasuh dan sekolah pertama bagi putra-putranya, sehingga Ilham dan Thareq tumbuh menjadi pribadi yang cerdas.

\section{Pokok-pokok pikiran feminisme dalam Novel Habibie\&Ainun karya Bacharuddin Jusuf Habibie}

Pokok pikiran feminisme dalam novel Habibie\&Ainun karya Bacharuddin Jusuf Habibie adalah sosok perempuan cerdas, kemandirian serta rela berkorban dan tangguh.

\section{Sosok Perempuan Cerdas}

Menurut Kamus Besar Bahasa Indonesia 2001, salah satu arti kata cerdas adalah tajam fikiran. Orang yang cerdas tidak hanya terpaku pada teori, namun lebih terhadap pemahaman konsep. Bagi orang cerdas senjata utamanya adalah logika dan pengetahuan yang ia dapat dari teori hanyalah sebagai pendukung. Kemampuan berfikir orang cerdas sangatlah cepat, sehingga ia sangat mudah mengerti, memahami dan menangkap maksud dari suatu kondisi atau keadaan.

Sosok perempuan cerdas dalam novel Habibie\&Ainun karya Bacharuddin Jusuf Habbie tercermin dari sosok Ainun yang memang mempunyai kemampuan lebih dalam berfikir. Disekolah Ia berprestasi, didunia 
kerja Ia dihormati dan di keluarga Ia dibanggakan. Semua itu tak lepas dari karunia Allah SWT yang telah memberikannya kecerdasan.

2. Kemandirian

Mandiri berarti mampu melakukan sesuatu tanpa mengharapkan bantuan dari orang lain. Orang yang mandiri adalah orang yang telah terbiasa melakukan apapun sendiri, karena ia akan terus belajar untuk tidak bergantung kepada orang lain. Kemandirian dalam novel Habibie\&Ainun karya Bacharuddin Jusuf Habibie tercermin dari sikap Ainun yang mampu mengerjakan pekerjaan rumah tangga secara mandiri, tanpa adanya bantuan dari asisten rumah tangga. Pekerjaan yang cukup menyita waktu banyak. Dilakukan setiap hari dan tidak nampak hasilnya karena tidak menghasilkan uang yaitu pekerjaan rumah tangga.

Kemampuannya dalam mengelola rumah tangga menunjukkan bahwa Ainun adalah sosok perempuan yang mandiri. Apa yang telah ia pelajari dulu dari ibunya kini sangat bermanfaat. Karena pada dasarnya kodrat wanita adalah mampu mengerjakan pekerjaan yang bersifat domestik yaitu pekerjaan rumah tangga. Pekerjaan rumah tangga diantaranya adalah: mengurus dan melayani kebutuhan suami, mengurus kebutuhan anak-anak, memasak, menyapu, mencuci, setrika, menjahit, belum lagi ika suami atau anak sakit ia juga harus merawat dan mengobati mereka. Karena kemampuannya ini lah sehingga perempuan adalah sosok yang mandiri.

3. Rela Berkorban dan Tangguh

Rela berkorban adalah keikhlasan dari dalam hati untuk memberikan apa yang dimiliki. Karena harus di dasarileh rasa ikhlas, maka tidak banyak orang yang mampu melakukannya. Saat ini banyak orang yang perhiungan terhadap kebaikan yang telah ia lakukan dan menuntut adanya timbal balik.

Sifat rela berkorban harus dibarengi dengan ketangguhan atau tahan banting. Tahan banting disini maksudnya bukan lah pekerja keras seperti kuli, tetapi lebih kepada kemampuan bertahan dari kerasnya hidup, mampu bertahan dari tekanan dan mampu melewati ujian kehidupan.

Dalam novel Habibie\&Ainun karya Bacharuddin Jusuf Habibie tercermin dari sikap Ainun yang mau mengabdikan dirinya untuk keluarganya dan mengorbankan karir dan profesinya serta kesenangannya demi menciptakan keluarga yang harmonis dan bahagia.

Ainun juga sosok perempuan tangguh karena berani mengawali kehidupan berumah tangga dari nol dengan kondisi yang pas-pasan hingga sekarang mempunyai materi yang sangat berlebih. Ketangguhannya dalam melawati segala ujian, rintangan dan hambatan kehidupan telah menjadikan pengorbanan yang ia berikan digantikan dengan harta yang tak ternilai dengan apapun. Yaitu kehidupan yang damai, harmonis dan bahagia.

\section{Nili Pendidikan dalam Novel Habibie \& Ainun karya Bacharuddin Jusuf Habibie}

1. Nilai Pendidikan Agama

Nilai agama merupakan perwujudan hubungan manusia dengan Allah SWT. Agama adalah pedoman hidup manusia. Dimana Allah SWT adalah 
tempat bergantung dan berlindung. Karena Allah SWT lah yang menentukan baik buruknya nasip seseorang sehingga kita patut meminta agar diberikan takdir yang baik.

Agama adalah ajaran yang diberikan oleh orang tua sejak lahir. Penanaman ilmu agama sangatlah penting dari sedini mugkin, dengan berbekal ilmu agama hati kita akan senantiasa dikendalikan dari perbuatan-perbuatan buruk yang akan merusak akhlak. Dengan ilmu agama kita aakan senantiasa bersyukur dan mensyukuri segala nikmat yang telah Allah SWT berikan sehingga dengan bersyukur Allah SWT akan menambahkan nikmatnya.

Nilai agama yang tercermin dari novel Habibie\&Ainun karya Bacharudddin Jusuf Habibie adalah rasa syukur yang selalu Habibie dan Ainun panjatkan disetiap doa-doa dan harapan-harapan yang digantungkan hanya kepada Allah SWT sebagai Tuhan yang akan memberikan takdir baik kepada seseorang. Habibie dan Ainun adalah sosok religius yang taat dengan perintah agama. Sehingga kehidupannya pun dipenuhi oleh keberkahan dari Allah SWT.

2. Nilai Pendidikan Moral

Nilai moral hampir sama dengan etika. Etika adalah perilaku seseorang yang mencerminkan tindakan yang baik, pantas atau tidak dan benar atau salah. Nilai tersebut dibangun dan berkembang dalam kehidupan masyarakat.

Karya sastra senantiasa menggambarkan pesan moral melalui tokohtokoh didalamnya. Nilai moral yang terkandung didalam novel Habibie\&Ainun karya Bacharuddin Jusuf habibie adalah : toleransi, saling menghormati dan menghargai, kasih sayang antar sesama dan rasa cinta terhadap tanah air dan bangsa.

3. Niai Pendidikan Sosial

Nilai sosial merupakan suatu nilai yang dianut oleh sekelompok masyarakat tentang sesuatu yang dianggap baik dan buruk oleh masyarakat.

Nilai sosial yang terkandung dalam novel biasanya menyangkut tentang kepedulian terhadap lingkungan sekitar. Yaitu hubungan antara manusia dengan manusia lainnya yang saling membutuhkan dan saling membantu dalam kebaikan sehingga tercipta suatu hubungan dan komunikasi yang baik yang kondusif dan nyaman.

Nilai pendidikan sosial yang terkandung di dalam novel Habibie\&Ainun adalah saat Ainun dijerman dan Ia belum mengenal lingkungan sekitar, namun ada tetangganya yang baik yang menawarkan diri memberikan bantuan jika Ainun membutuhkan.

Nilai sosial lain juga tercermin dari sikap Ainun yang mau menampung anak sepupunya dirumahnya guna mendapat pendidikan dan pengasuhan yang baik sesuai dengan bidang yang diminati.

4. Nilai Pendidikan Budi Pekerti

Hubungan antara manusia dengan dirinya sendiri, hubungan manusia denga manusia lain, hubungan antara manusia dengan lingkungan atau alam dan hubungan manusia dengan Tuhan sering menjadikisah dalam karya sastra diantaranya adalah novel. Sehingga manusia harus mampu berhubungan dengan siapa saja. 


\section{Diskursus: Jurnal Pendidikan Bahasa Indonesia}

Vol. 3, No. 3, Desember 2020, pp. 299-310

p-ISSN: 2615-4935

e-ISSN: 2615-4943

Nilai budi pekerti adalah perilaku atau sikap halus budi seseorang yang ditunjukkan melalui perbuatan atau tindakan. Nilai budi pekerti mencerminkan baik buruknya kepribadian seseorang.

Nilai budi pekerti yang tercermin dari novel Habibe\&Ainun adalah sikap Ainun yang selalu ramah dan disertai dengan senyuman menunjukkan bahwa Ia adalah sosok perempuan yang halus dan lembut dalam menghadapi suaminya. Sikap itu ditunjukkan untuk menghormati suaminya. Rasa cinta, kasih sayang dan setianya kepada Habibie juga merupakan bentuk nilai budi pekerti.

Berdasarkan penjabaran di atas, bahwa kajian feminisme dan nilai pendidikan dalam novel habibie \& Ainun karya Bacharuddin Jusuf Habibie adalah sebagai berikut : (1) Aspek-aspek Feminisme dalam novel Habibie\&Ainun karya Bacharuddin Jusuf Habibie yaitu : (a) Aspek Feminisme dalam Bidang Pendidikan. Aspek feminisme dalam bidang pendidikan pada novel Habibie\&Ainun adalah dimana seorang perempuan diperbolehkan menuntut ilmu dalam bidang apapun sesuai dengan kemampuan, minat dan bakatnya masing-masing tanpa adanya larangan untuk mengembangkan potensi yang dimiliki. (b) Aspek Feminisme dalam Bidang Pekerjaan/Karir. Perempuan mendapat kesempatan yang sama dan hak yang sama dalam bekarya tanpa adanya diskriminasi mengenai upah atau jabatan dalam sebuah instansi. Semua disesuaikan dengan kemampuan dan kecerdasan masing-masing. (c) Aspek Feminisme dalam Bidang Rumah Tangga. Meskipun berprofesi sebagai ibu rumah tangga, namun jika diberi kebebasan untuk mengatur dirinya sendiri tetap dinamakan feminis. Tidak dikekang, ditekan ataupun diakui sebagai hak milik. Karena pada dasarnya perempuan juga mempunyai hak untuk merdeka meskipun ia telah menikah dan hidup sebagai ibu rumah tangga. (2) Eksistensi Perempuan dalam novel Habibie\&Ainun karya Bacharuddin Jusuf Habibie yaitu : (a) Kedudukan sama dalam bidang pendidikan dan pekerjaan/karir. Pendidikan adalah jendela dunia karena terdapat berbagai ilmu didalamnya. Sehingga sudah sepatutnya jika perempuan mendapatkan hak dan pengakuan yang sama dalam bidang pendidikan maupun dalam pekerjaan/karir. (b) Kebebasan menentukan pilihan. Dunia patriarki menggambarkan bagaimana seorang perempuan ada dalam penguasaan laki-laki. Sehingga perempuan kesulitan menentukan pilihan hidupnya sendiri. Perempuan berhak menentukan piliannya sendiri. (c) Berperan penting sebagai istri dan ibu dalam rumah tangga. Peran sebagai istri dan ibu inilah yang menentukan keberhasilan dalam membangun rumah tangga. Karena dibalik kesuksesan laki-laki pasti ada perempuan hebat yang mendampinginya, serta dalam melahirkan, pengasuhan dan pendidikan anak semua adalah ibu yang berperan. Ibulah yang menentukan pendidikan dan masa depan yang baik untuk anak-anaknya. (3) Pokok-pokok Pikiran Feminisme dalam novel Habibie\&Ainun karya Bacharuddin Jusuf Habibie yaitu : (a) Sosok perempuan cerdas. Cerdas adalah kemampuan berinovasi dan improvisasi karena dasarnya adalah ketajaman fikiran. Perempuan cerdas akan mampu melakukan dan menguasai lebih daru satu bidang ilmu. (b) Kemandirian. Mandiri adalah sikap yang tidak mengharapkan bantuan dari orang lain. Yaitu melakukan pekerjaan secara mandiri tanpa bergantung kepada orang lain dalam menyelesaikannya. (c) Rela

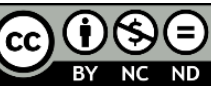

Creative Commons Attribution-NonCommercial-NoDerivatives 4.0 International License 
berkorban dan tangguh. Keikhlasan Ainun untuk melepaskan kesenangannya, hobbynya, pekerjaanya, profesinya dan penghasilannya untuk mengabdikan diri pada keluarga kecilnya. (4) Nilai-nilai Pendidikan dalam novel Habibie\&Ainun karya Bacharuddin Jusuf Habibie yaitu : (a) Nilai pendidikan Agama. (b) Nilai pendidikan Moral. (c) Nilai Pendidikan Sosial. (d) Nilai Pendidikan Budi Pekerti.

\section{SIMPULAN}

Berdasarkan hasil dan pembahasan, dapat disimpulkan hal-hal sebagai berikut: (1) Aspek-aspek Feminisme dalam novel Habibie\&Ainun karya Bacharuddin Jusuf Habibie yaitu: (a) Aspek Feminisme dalam Bidang Pendidikan. (b) Aspek Feminisme dalam Bidang Pekerjaan/Karir. (c) Aspek Feminisme dalam Bidang Rumah Tangga. (2) Eksistensi Perempuan dalam novel Habibie\&Ainun karya Bacharuddin Jusuf Habibie yaitu: (a) Kedudukan sama dalam bidang pendidikan dan pekerjaan/karir. (b) Kebebasan menentukan pilihan. (c) Berperan penting sebagai istri dan ibu dalam rumah tangga. (3) Pokok-pokok Pikiran Feminisme dalam novel Habibie\&Ainun karya Bacharuddin Jusuf Habibie yaitu : (a) Sosok perempuan cerdas. (b) Kemandirian. (c) Rela berkorban dan tangguh. (4) Nilai-nilai Pendidikan dalam novel Habibie\&Ainun karya Bacharuddin Jusuf Habibie yaitu: (a) Nilai pendidikan Agama. (b) Nilai pendidikan Moral. (c) Nilai Pendidikan Sosial (d) Nilai Pendidikan Budi Pekerti.

Saran ini terutama ditujukan kepada para pendidik dan peserta didik, yaitu (1) Untuk Pendidik: Novel Habibi\&Ainun karya Bacharuddin Jusuf Habibi sangat baik digunakan sebagai referensi dan bahan ajar dalam bidang sastra. (2) Untuk Peserta Didik: Peserta didik dapat membuat simpulan tentang baik buruknya isi novel. Jika itu positif dapat diambil hikmahnya dan dijadikan sebagai contoh dalam kehidupan, namun jika itu negatif maka dapat dihindari jangan sampai terjadi dikehidupan mendatang.

\section{DAFTAR PUSTAKA}

Arikunto, S. (2010). Metode peneltian. Jakarta: Rineka Cipta.

Djajanegara, S. (2000). Kritik sastre feminis: Sebuah pengantar. Jakarta: Gramedia Pustaka Utama

Habibie, B. J. (2013). Habibi \& Ainun. Jakarta: PT. THC Mandiri.

Minderop, A. (2010). Psikologi sastra: Karya, metode, teori, dan contoh kasus. Yayasan Pustaka Obor Indonesia.

Rokhmansyah, A. (2016). Pengantar gender \& feminisme: Pemahaman awal kritik sastra feminisme. Yogyakarta: Garudhawaca

Semi, M. A. (1988). Anatomi sastra. Angkasa Raya.

Sukron, A. (2009). Islam dan feminisme (Perspektif rekonstruksi hukum Islam). Muwazah: Jurnal Kajian Gender, 1(2), 135-146. 